\title{
Removal of Nutrients from Fertilizer Plant Wastewater Using Scenedesmus sp.: Formation of Bioflocculation and Enhancement of Removal Efficiency
}

\author{
Thanh-Luu Pham (iD ${ }^{1,2}$ and Manh Ha Bui $\mathbb{D}^{3,4}$ \\ ${ }^{1}$ Ho Chi Minh City University of Technology (HUTECH), 475A Dien Bien Phu Street, Ward 25, Binh Thanh District, \\ Ho Chi Minh City 700000, Vietnam \\ ${ }^{2}$ Institute of Tropical Biology, Vietnam Academy of Science and Technology (VAST), 85 Tran Quoc Toan Street, District 3, \\ Ho Chi Minh City 700000, Vietnam \\ ${ }^{3}$ Institute of Research and Development, Duy Tan University, 182 Nguyen Van Linh Street, Thanh Khe District, \\ Da Nang City 550000, Vietnam \\ ${ }^{4}$ Department of Environmental Science, Saigon University, 273 An Duong Vuong Street, District 5, \\ Ho Chi Minh City 700000, Vietnam \\ Correspondence should be addressed to Thanh-Luu Pham; pt.luu@hutech.edu.vn
}

Received 23 August 2019; Accepted 10 January 2020; Published 14 February 2020

Guest Editor: Shanshan Chang

Copyright (c) 2020 Thanh-Luu Pham and Manh Ha Bui. This is an open access article distributed under the Creative Commons Attribution License, which permits unrestricted use, distribution, and reproduction in any medium, provided the original work is properly cited.

\begin{abstract}
Eutrophication of surface water has become an environmental concern in recent decades. High concentrations of nutrients, especially nitrogen- and phosphorus-rich species, have contributed to the process of eutrophication, highlighting a demand for effective and economical methods of removing nitrogen and phosphorus from wastewater. This study aimed to investigate the ability of a green microalga species, Scenedesmus sp., to remove nitrogen and phosphorus, as well as chemical oxygen demand $(\mathrm{COD})$ and biochemical oxygen demand $\left(\mathrm{BOD}_{5}\right)$, from fertilizer plant wastewater. Different microalgae concentrations from $10 \mathrm{mg} / \mathrm{L}$ to $60 \mathrm{mg} / \mathrm{L}$ were used to assess the growth rate, biomass production, and removal ability. The results indicated that Scenedesmus sp. grew well in the wastewater (with a growth rate from 0.3 to 0.38 /day) and produced up to $70.2 \mathrm{mg} / \mathrm{L}$ of dry biomass. The algal species was able to remove ammonium $\left(\mathrm{NH}_{4}^{+}\right)$, nitrate $\left(\mathrm{NO}_{3}^{-}\right)$, phosphate $\left(\mathrm{PO}_{4}^{3-}\right)$, total phosphorus (TP), COD, and $\mathrm{BOD}_{5}$ with removal rates up to $93 \%, 84 \%, 97 \%, 96 \%, 93 \%$, and $84 \%$, respectively. Autobioflocculation (AFL) was observed in all cultures with flocculation activity of up to $88.3 \%$ in the highest algal biomass treatment. The formation of bioflocculation enhanced the removal of nutrients, $\mathrm{COD}$, and $\mathrm{BOD}_{5}$ from wastewater effluent. The results indicated that wastewater from a fertilizer plant could be used as a cost-effective growth medium for algal biomass. The autoflocculation of microalgae could be used as a more practical approach for wastewater treatment using microalgae to eliminate eutrophication.
\end{abstract}

\section{Introduction}

In recent decades, the intensity of agricultural and industrial activities, together with rapid urbanization, has generated large amounts of wastewaters [1]. The continuous disposal of wastewaters without appropriate treatment to water sources has posed severe water pollution problems, especially in developing countries [2]. These effluents contain a high concentration of nutrients such as nitrogen and phosphorus, which are the leading causes of eutrophication in natural waters [3]. This condition is favorable for the development of harmful algal blooms (HABs) resulted in the degradation of water quality and impairment of freshwater ecosystems [4]. Moreover, the occurrence of HABs can result in serious problems such as anoxic conditions, toxin productions, killing of fish, and altered biodiversity [5]. HABs are considered a public health risk due to produce a variety of toxic secondary metabolisms [6]. For these reasons, many efforts 
have been done in order to mitigate eutrophication by reducing nitrogen and phosphorus concentration in wastewater effluents before discharging into water sources.

To mitigate eutrophication, nutrient control is a fundamental process [7]. Physical and chemical methods have been developed for the removal of nutrients from wastewater, but these are costly and produce high sludge content [8]. Due to requiring large amounts of the nutrient, especially nitrogen and phosphorus for growth, many species of green microalgae such as Chlorella sp., Scenedesmus sp., and Neochloris sp. have been proposed as an alternative biological treatment to remove nitrogen and phosphorus from a different sources of wastewater for many years $[2,8,9]$. Indeed, extensive studies have been carried out on the subject of microalgae cultivation using wastewater. High removal efficiencies of nitrogen and phosphorus (more than $80 \%$ ) from wastewaters of different sources have already been recorded for several microalgae species [9-12].

Recent evidence indicated that the formation of microalgae-bacteria flocculation (MBF) and fungi-assisted microalgae pellets (FAMP) enhanced nutrient removal from wastewater effluent $[13,14]$. While MBF is a flocculation formation of microalgae cells assisted with bacteria, FAMP is a pellet formation of microalgae cells supported with fungi $[14,15]$. During bioflocculation formation, the aggregation of bacteria or fungi and microalgae cells creates large flocs or pellets which accelerate the adsorption of suspended compounds in surrounding medium to form co-bioflocculate and thus enhance the removal efficiency of nitrogen and phosphorus [14-16]. Therefore, MBF and FAMP have been used to improve nutrient removal and effluent recovery in aerobic-activated sludge technologies $[13,15,17]$. The bioflocculation of microalgae and bacteria have been intensively studied and reviewed for recent advances and perspectives [18-20]. Besides, MBF can be used as a promising low-cost method for harvesting microalga biomass $[14,21]$.

Another flocculation can occur naturally in certain microalgae in response to some environmental stress, which is so-called autoflocculation (AFL) [14]. However, little is known about AFL of microalgae. Moreover, the driving factor for the formation of AFL is not understood yet. Therefore, it is vital to pay more attention to the technique to obtain more knowledge about AFL formation and enhance its application.

The fertilizer industry is one of the most important economic sectors in Vietnam due to its economy is based on agriculture. Wastewaters from fertilizer plants contained a variety of nutrients include nitrogen and phosphorous compounds that is a significant problem of water eutrophication [22]. In the present study, wastewater effluent obtained from Phu My Fertilizer Plant (Vietnam) was used as a culture medium for microalgae production. The present study aimed to investigate the nutrient removal ability of a native microalga Scenedesmus sp. species. Furthermore, the biomass growth, flocculating activity, chemical oxygen demand (COD) and biochemical oxygen demand $\left(\mathrm{BOD}_{5}\right)$ removal, dry matter and chlorophyll content of the flocs collected, and the wastewater nutrient removal were studied in order to evaluate the potential use of the microalgae for controlling eutrophication and producing renewable energy.

\section{Materials and Methods}

2.1. Wastewater Sample Collection and Characterization. The wastewater used in the present study was collected from equation tanks (ET) in the Phu My Fertilizer Wastewater Plant (Vietnam). Samples for wastewater characterization were immediately stored at $4^{\circ} \mathrm{C}$ prior to analysis. The microalgae sample was collected from a similar ET by using a phytoplankton net. Dissolved oxygen (DO), temperature, and water $\mathrm{pH}$ were measured in situ with a multiparameter meter (Hach 156, USA). Before using for all the experiments throughout this study, the wastewater was filtered through $0.45 \mu \mathrm{m}$ filters to remove the suspended grease layer.

2.2. Isolation of Microalgae from Wastewater. The microalgae sample was enriched separately in different flasks with COMBO medium [23] prior to isolation. Samples were screened under a microscope. Scenedesmus sp. was dominant in wastewater. Colonies of Scenedesmus sp. (Figure 1) were isolated by micropipetting and washing. All cultures were maintained under laboratory conditions at a temperature of $27^{\circ} \mathrm{C}, 12 \mathrm{~h}$ light photoperiods, and light intensity of $50 \mu \mathrm{mol}$ photons $/ \mathrm{m}^{2} / \mathrm{s}$. The axenic strains were cultured in conical flasks containing a sterile liquid medium.

The microalgae biomass was measured using the gravimetric method. A $20 \mathrm{~mL}$ sample was placed in a preweighed glass tube. After centrifugation at $4000 \mathrm{rpm}$ for 15 minutes, the supernatant was discarded, and then the tubes were dried at $105^{\circ} \mathrm{C}$ for 24 hours and reweighted. The dry biomass was calculated gravimetrically by weight difference. Samples were prepared in triplicate for calculation of the standard errors.

2.3. Experimental Setup. Precultures showed that Scenedesmus sp. grew well in cultured medium at room temperature $\left(27 \pm 1^{\circ} \mathrm{C}\right)$ under 12 hour photoperiods with the light intensity of $95 \mu \mathrm{mol}$ photons $/ \mathrm{m}^{2} / \mathrm{s}$. Therefore, this condition was selected for conducting the experiments. Batch experiments were conducted in triplicate with an initial $\mathrm{pH}$ of $7.3 \pm 0.5$ (no $\mathrm{pH}$ control) by using $1000 \mathrm{~mL}$ flasks placed in a shaker at $70 \mathrm{rpm}$. Each flask with $800 \mathrm{~mL}$ of wastewater inoculated with a suspension of precultured cells. The initial biomass was prepared at 10,20,30,40, and $60 \mathrm{mg}$ dry weight (DW)/L. Illumination was provided continuously by linear fluorescent lamps using 12 hour photoperiods for 10 days. The flasks containing wastewater without microalgae cells were used as controls. The single-isolated microalga was used for the experiment. $1 \mathrm{~mL}$ sample was collected every day to determine optical density. Samples for measurement nutrients concentration were prepared by withdrawing $100 \mathrm{~mL}$ from flasks at three-day interval. And then, the samples were centrifuged at $5000 \mathrm{rpm}$ for $10 \mathrm{~min}$ to remove the microalga cells, and the supernatant was collected for analysis of nutrients concentration in the same 


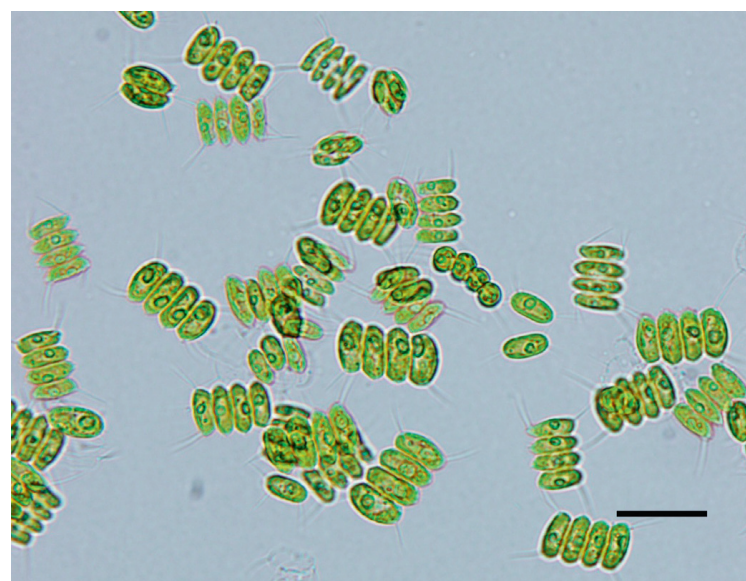

Figure 1: Morphology of colonies of Scenedesmus sp. under a microscope. Scale bar: $20 \mu \mathrm{m}$.

days. Dry microalga biomass and total lipid content were determined at the beginning and end of the bioassays.

2.4. Measurement of the Growth Rate and Flocculation Activity. The growth rate (GR) of the microalgae was calculated as follows:

$$
\mathrm{GR}=\ln \frac{\left(N_{t} / N_{0}\right)}{\left(T_{t}-T_{0}\right)},
$$

where $N_{t}$ and $N_{0}$ are the microalgae biomass $(\mathrm{mg} / \mathrm{L})$ at the end $\left(T_{t}\right)$ and start $\left(T_{0}\right)$ of the growth phase, respectively.

The flocculation activity (FA) was measured according to the method reported previously by Nguyen et al. [13] as follows:

$$
\mathrm{FA}(\%)=\left(1-\frac{\mathrm{OD}_{680 t}}{\mathrm{OD}_{680 t 0}}\right) \times 100,
$$

where $\mathrm{OD}_{680 t}$ is the optical density of the sample at time $t$ and $\mathrm{OD}_{680 t 0}$ is the optical density at time $t_{0}$.

2.5. Chlorophyll Content. To determine the chlorophyll (Chl) content of microalgae, a known volume of culture samples $(1 \mathrm{~mL})$ was centrifuged at $5000 \mathrm{rpm}$ for $10 \mathrm{~min}$. After discarding the supernatant, Chl from microalgae cells was extracted with $3 \mathrm{~mL}$ of methanol (100\%) overnight in the dark at room temperature. Then, the suspension was centrifuged at $10000 \mathrm{rpm}$ for $10 \mathrm{~min}$ to remove the cell debris. After centrifugation, the supernatant was used to measure Chl content $652 \mathrm{~nm}$ (Chl-b), $665 \mathrm{~nm}$ (Chl-a), and $750 \mathrm{~nm}$ (turbidity of suspension) by using a spectrophotometer (UV-VIS, Harch, 500), and the concentration of Chl $(\mu \mathrm{g} / \mathrm{mL})$ was calculated as follows [24]:

$$
\mathrm{Chl}=\left[-8.0962\left(\mathrm{OD}_{652}-\mathrm{OD}_{750}\right)+16.5169\left(\mathrm{OD}_{665}-\mathrm{OD}_{750}\right)\right] \frac{V_{2}}{V_{1} l}
$$

where $V_{1}$ and $V_{2}$ are the volume of sample suspension and methanol used, respectively. And, $l$ is the optical path, which is $1 \mathrm{~cm}$.
2.6. Measurement of Wastewater Quality Parameters. Wastewater quality parameters including ammonium $\left(\mathrm{NH}_{4}^{+}\right)$, nitrate $\left(\mathrm{NO}_{3}^{-}\right)$and phosphate $\left(\mathrm{PO}_{4}^{3-}\right)$, total nitrogen (TN), total phosphate and total suspended solids (TSS), biochemical oxygen demand $\left(\mathrm{BOD}_{5}\right)$, and chemical oxygen demand (COD) were analyzed according to the Standard Methods for Examination of Water and Wastewater [25].

The efficiency of nutrient removal $\left(E_{r}\right)$ in wastewater was expressed in

$$
E_{r}(\%)=\frac{C_{o}-C_{f}}{C_{o}} \times 100,
$$

where $C_{o}$ and $C_{f}$ are the initial and final concentrations of nutrients concentration in wastewater effluent.

2.7. Statistical Analysis. The differences between mean values of the specific growth rate, dry microalga biomass, and pollutant removal rates were tested for significance using a one-way analysis of variance (ANOVA). $P$ values $\leq 0.05$ were considered significant differences. All results are presented in the form of mean values \pm standard deviation from three samples.

\section{Results and Discussion}

3.1. Characteristics of Wastewater. The wastewater used for the experiment was analyzed for evaluating physicochemical characteristics. The physico-chemical parameters of the wastewater, including $\mathrm{pH}$, temperature, main nutrient species, as well as $\mathrm{BOD}_{5}$ and $\mathrm{COD}$ were presented in Table 1. The wastewater effluent collected from the Phu My Fertilizer Plant contained large amounts of nitrogen $(47.3 \pm 5.9 \mathrm{mg} / \mathrm{L})$ in the form of ammonium $\left(\mathrm{NH}_{4}^{+}\right)$and nitrate $\left(\mathrm{NO}_{3}^{-}\right)$with small amounts of phosphate $\left(\mathrm{PO}_{4}^{3-}\right)(0.9 \pm 0.28 \mathrm{mg} / \mathrm{L})$. Besides, the initial $\mathrm{pH}$ of the wastewater effluent was almost constant at pH 6.8. Ammonium is among the most common chemical forms of nitrogen that can be readily absorbed by most microalga species [26]. The concentration of phosphorus was also found sufficient to support algal growth. In this respect, the effluent collected from the Phu My Fertilizer Wastewater Treatment Plant could be used as a cheap source of nutrients for microalgal cultivation. The characterized of the raw wastewater was noted to be favorable for microalgae growth. A ratio of COD/TN/TP, i.e., 180/47/2, found with this wastewater, is suitable for nutrient removal with microalgae. The $\mathrm{BOD}_{5} / \mathrm{TP}, \mathrm{BOD}_{5} / \mathrm{PO}_{4}^{3--}$, and $\mathrm{PO}_{4}^{3-} / \mathrm{TP}$ ratios were found to be reasonably high (Table 1 ). The optimal inorganic N/P ratio for freshwater algae growth was suggested to be in the range of 6.8-10 [27, 28]. In this study, the inorganic N/P ratio of the effluent was 21, much higher than the optimal ratio, indicating the wastewater as phosphorus limitation media.

3.2. Growth of Scenedesmus sp. in Wastewater. The green algae Scenedesmus sp. was cultivated in the wastewater for 10 days with different initial cell concentrations from 10 to $60 \mathrm{mg} / \mathrm{L}$. The growth rate, Chl content, and flocculation 
TABLE 1: The average composition of the wastewater (average \pm SD of five samples).

\begin{tabular}{lcc}
\hline Parameter & Unit & Value \\
\hline $\mathrm{pH}$ & & $6.8 \pm 0.5$ \\
Temperature & ${ }^{\circ} \mathrm{C}$ & $29 \pm 1.0$ \\
Dissolved oxygen $(\mathrm{DO})$ & $\mathrm{mg} / \mathrm{L}$ & $4.7 \pm 0.6$ \\
Ammonium $\left(\mathrm{NH}_{4}^{+}\right)$ & $\mathrm{mg} / \mathrm{L}$ & $26.5 \pm 3.5$ \\
Nitrate $\left(\mathrm{NO}_{3}^{-}\right)$ & $\mathrm{mg} / \mathrm{L}$ & $11.3 \pm 2.1$ \\
Phosphorus $\left(\mathrm{PO}_{4}^{3+}\right)$ & $\mathrm{mg} / \mathrm{L}$ & $0.9 \pm 0.28$ \\
Total nitrogen $(\mathrm{TN})$ & $\mathrm{mg} / \mathrm{L}$ & $47.3 \pm 5.9$ \\
Total phosphorus $(\mathrm{TP})$ & $\mathrm{mg} / \mathrm{L}$ & $1.8 \pm 0.27$ \\
Chemical oxygen demand (COD) & $\mathrm{mg} / \mathrm{L}$ & $180 \pm 18$ \\
Biochemical oxygen demand $\left(\mathrm{BOD}_{5}\right)$ & $\mathrm{mg} / \mathrm{L}$ & $87 \pm 12$ \\
Inorganic N/P & & 21 \\
\hline
\end{tabular}

activity were presented in Table 2 . The microalgae grew well in the wastewater with the growth rate from 0.30 to 0.38 /day. There was no significant difference in the growth rate as the initial microalgae concentration increased from 10 to $60 \mathrm{mg}$ / L. In the present study, wastewater was used as a nutrient medium for the growth of microalgae, and the utilization of nutrients allows wastewater treatment. During the growth phase, microalgae consumed mineral nutrients and $\mathrm{CO}_{2}$ from wastewater to produce biomass and released $\mathrm{O}_{2}$ into the medium [29].

Our results showed that flocculation activity increases with higher cell concentrations. Significant build up of flocculation activity ( 81.5 and $88.3 \%$ ) was observed at the highest initial microalgae concentrations of 40 and $60 \mathrm{mg} /$ L. Nguyen et al. [13] reported that the clear formation of flocculation occurred when Chlorella vulgaris in seafood wastewater with the initial concentration above $20 \mathrm{mg} / \mathrm{L}$. Results of the present study are consistent with previous observations that higher initial biomass in the medium a better formation of flocculation because cell-cell encounters are more frequent, leading to better aggregation $[30,31]$. Microalgal bioflocculation is an efficient low-cost technology for microalgal harvesting and wastewater treatment $[14,21,32]$. In general, the bioflocculation process is assisted with microorganisms (including bacteria, fungi, and yeasts) or their polymer substances [13-15]. Since no chemical is added in this process, the bioflocculation has been considered as a sustainable and green technique for algal biomass harvesting $[14,15]$. The formation of algal flocculation and its application in wastewater treatment has been reviewed in detail $[14,15,18]$. In the present study, autoflocculation occurred when cultured Scenedesmus sp. in the wastewater for 10 days. Microalgal autoflocculation was found to be associated with increase in culture $\mathrm{pH}$ levels, due to $\mathrm{CO}_{2}$ consumption by algal photosynthetic activity. Under these alkaline conditions, some metal ions precipitated together with the algal biomass [33]. Guo et al. [31] reported that cell wall-associated polysaccharides mediated self-flocculation of the microalga S. obliquus. Future study is needed in this area to understand the mechanism of self-flocculation of microalgal cells and increase application in wastewater treatment technology.
3.3. Removal of Nitrogen. Nutrient removal in different initial biomass (from 10 to $60 \mathrm{mg} / \mathrm{L}$ ), including $\left(\mathrm{NH}_{4}^{+}, \mathrm{NO}_{3}^{-}, \mathrm{PO}_{4}^{3-}\right.$ and TP) during the experiment, are shown in Figure 2. The removal rate of $\mathrm{NH}_{4}^{+}$in the control (no microalgae) was $21.1 \%$, and all treatment with Scenedemsus sp. achieved higher removal than in the control. The $\mathrm{NH}_{4}^{+}$and $\mathrm{NO}_{3}^{-}$removal performance is shown in Figures 2(a) and 2(b) with the removal efficiencies from 71.7 to $92.8 \%$ and from 62.2 to $83.6 \%$, respectively (Table 3 ). In general, the higher microalgal concentration resulted in higher removal efficiency of $\mathrm{NH}_{4}^{+}$ and $\mathrm{NO}_{3}^{-}$. This observation well agreed with previous studies that higher initial microalgae density enhanced nutrient uptake in different wastewater effluents [13, 34, 35]. Green algae can use a variety of nitrogen sources for growth, making it possible to use these algae for bioremediation to remove nitrogen from wastewater [26, 28]. Microalgae can convert different inorganic nitrogen forms from wastewater to organic nitrogen [15]. Previous studies have demonstrated that the major mechanisms of nitrogen removal in algae systems include nitrification or denitrification and biological uptake of nitrogen by dispersed biomass $[34,36]$.

Nitrification was observed during the first four days of the experiment; the decrease in ammonium concentration was accompanied by nitrate formation that peaked at day fourth and then decreased (Figures 2(a) and 2(b)). Although ammonium is the preferred nitrogen source for uptake, microalgae can consume nitrogen from a variety of nitrogen sources, including ammonium, nitrate, nitrite, and urea $[26,28,36]$. Since the removal efficiencies on nitrate are usually lower than those on ammonium, our results agree well with previous observations that green microalgae such as Chlorella and Scenedemus were the preference for ammonium to any other form of nitrogen present in wastewater [34, 37].

3.4. Removal of Phosphorus. The removal rate of $\mathrm{PO}_{4}^{3-}$ and TP were shown in Table 3 and Figures 2(c) and 2(d). The percentages of $\mathrm{PO}_{4}^{3-}$ and TP removal for the control were only 17.5 and $26.8 \%$, respectively. While in the treatment, this number ranged from $94.7 \%$ to $97.0 \%$ and from $75 \%$ to 95.8\% for $\mathrm{PO}_{4}^{3-}$ and $\mathrm{TP}$, respectively. The removal efficiencies were not significant differences $(P=0.227)$ as treating $\mathrm{PO}_{4}^{3-}$ with different concentrations of algal biomass. However, more significant TP removal rates were found during the treatment of wastewater with higher initial algae concentration ( 40 and $60 \mathrm{mg} / \mathrm{L}$ ), compared with lower algae concentrations $(10,20$, and $30 \mathrm{mg} / \mathrm{L})$. The removal rates of TP were a significant correlation with the flocculation activities.

Removal of $\mathrm{PO}_{4}^{3-}$ up to $97 \%$ (Table 3) from wastewater treated with green algae Scenedesmus sp. was very effective. For all treatments, the concentration of $\mathrm{PO}_{4}^{3-}$ decreased gradually during ten days of the experiment (Figure 2(c)). But for TP, high removal rates were only found in the treatments with 40 or $60 \mathrm{mg} / \mathrm{L}$. The concentration of TP did not decrease significantly during the first two days of the experiment but rapidly reduced from day 2 to day 6 of the test (Figure 2(d)). 
TABLE 2: The growth rate, chlorophyll content, and flocculation activity.

\begin{tabular}{|c|c|c|c|c|c|}
\hline & \multicolumn{5}{|c|}{ Initial microalgae concentration $(\mathrm{mg} / \mathrm{L})$} \\
\hline & $10 \pm 0.9$ & $20 \pm 1.3$ & $30 \pm 1.6$ & $40 \pm 1.2$ & $60 \pm 1.5$ \\
\hline Growth rate/day & $0.3 \pm 0.03$ & $0.34 \pm 0.02$ & $0.36 \pm 0.02$ & $0.37 \pm 0.03$ & $0.38 \pm 0.04$ \\
\hline Chlorophyll (mg/L) & $13.7 \pm 1.8$ & $14.5 \pm 1.6$ & $18.2 \pm 1.9$ & $19.4 \pm 2.3$ & $20.8 \pm 2.5$ \\
\hline Dry biomass $(\mathrm{g} / \mathrm{L})$ & $30.5 \pm 2.8$ & $35.8 \pm 3.3$ & $42.1 \pm 2.7$ & $68.3 \pm 3.6$ & $70.2 \pm 4.9$ \\
\hline Flocculation activity (\%) & $14.2 \pm 1.8$ & $23.7 \pm 4.3$ & $41.6 \pm 2.3$ & $81.5 \pm 5.7$ & $88.3 \pm 4.1$ \\
\hline
\end{tabular}

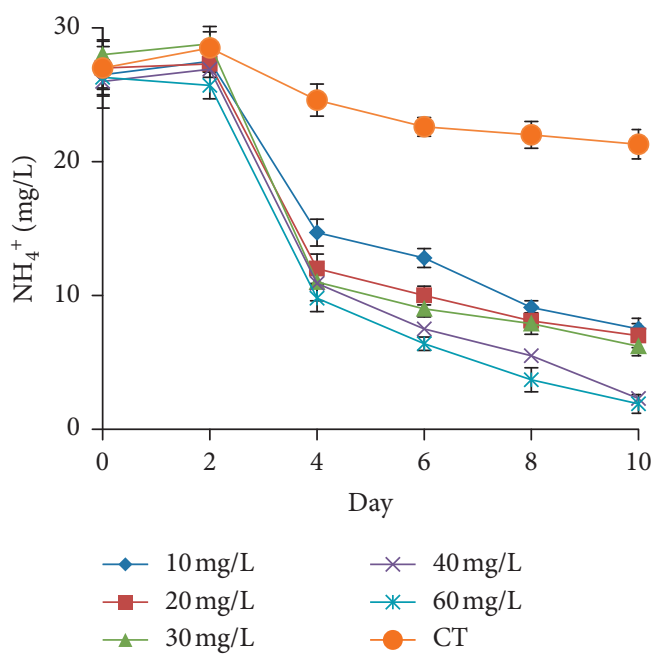

(a)

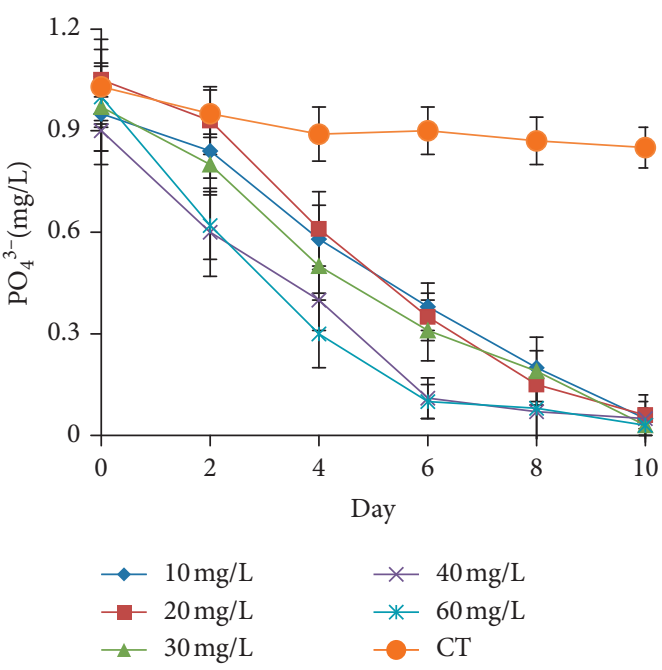

(c)

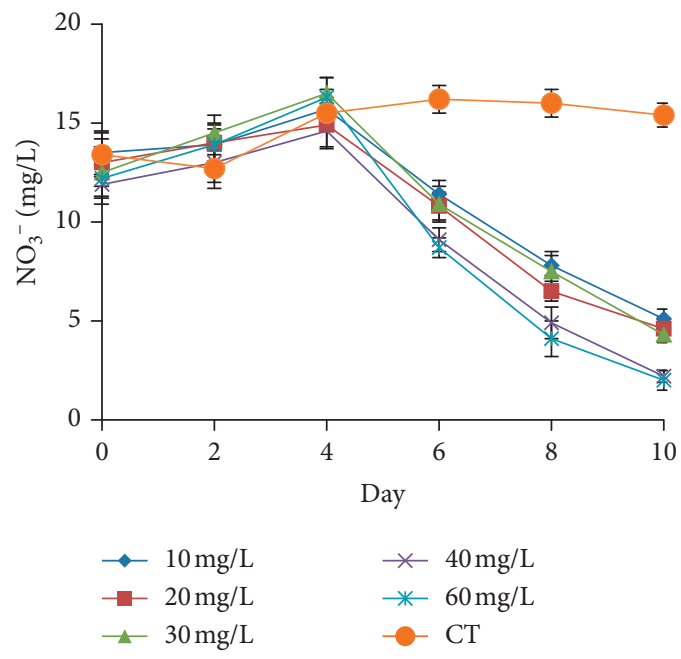

(b)

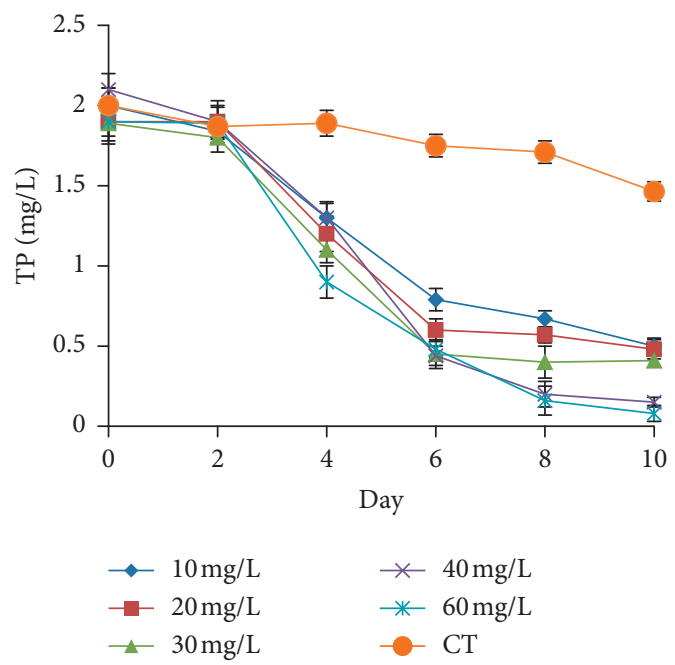

(d)

FIgure 2: Continued. 


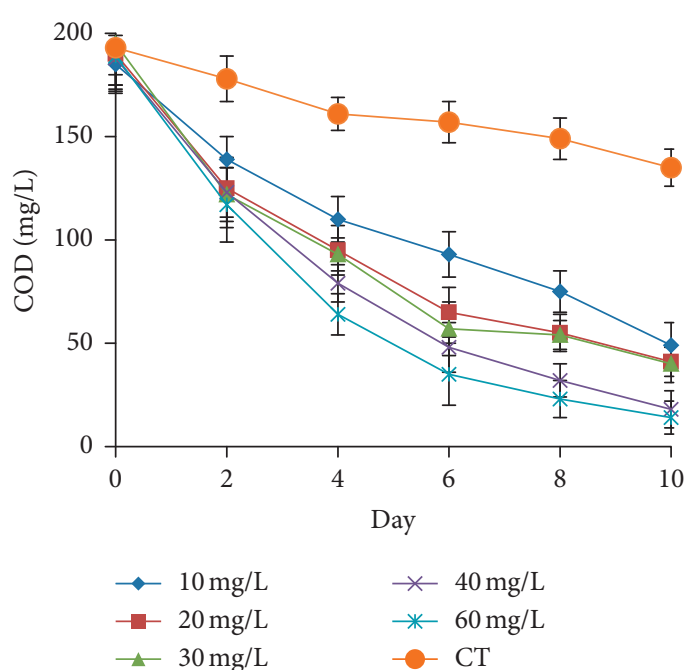

(e)

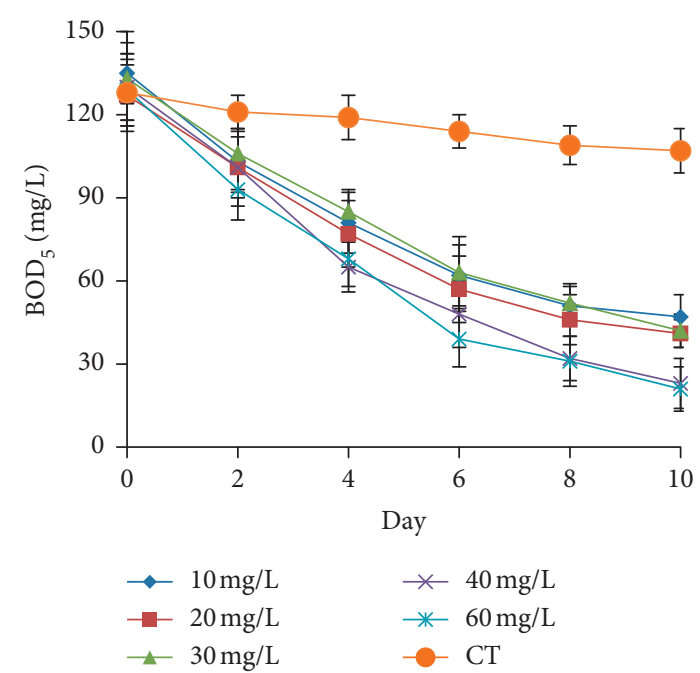

(f)

Figure 2: Changes of $\mathrm{NH}_{4}^{+}$(a), $\mathrm{NO}^{-}$(b), $\mathrm{PO}_{3}^{-}$(c), TP (d), COD (e), and BOD5 (f) concentrations in the treatment with different initial microalgae concentrations.

TABle 3: Flocculation activity and removal efficiency with different initial microalgae concentration.

\begin{tabular}{|c|c|c|c|c|c|c|c|}
\hline \multirow{2}{*}{ Initial microalgae concentration } & \multirow{2}{*}{ Flocculation activity (\%) } & \multicolumn{6}{|c|}{ Removal efficiency (\%) } \\
\hline & & Ammonium & Nitrate & Phosphate & $\mathrm{TP}$ & $\mathrm{COD}$ & $\mathrm{BOD}_{5}$ \\
\hline Control & & $21.1 \pm 1.4$ & $-14.9 \pm 3.3$ & $17.5 \pm 2.1$ & $26.8 \pm 2.7$ & $28.1 \pm 2.0$ & $16.4 \pm 1.1$ \\
\hline $10 \mathrm{mg} / \mathrm{L}$ & $14.2 \pm 1.8$ & $71.7 \pm 1.9$ & $62.2 \pm 2.8$ & $94.7 \pm 1.5$ & $75.0 \pm 3.6$ & $73.5 \pm 3.4$ & $65.2 \pm 1.4$ \\
\hline $20 \mathrm{mg} / \mathrm{L}$ & $23.7 \pm 4.3$ & $74.1 \pm 2.1$ & $64.6 \pm 3.0$ & $94.5 \pm 2.3$ & $74.7 \pm 1.9$ & $78.4 \pm 2.4$ & $67.7 \pm 1.8$ \\
\hline $30 \mathrm{mg} / \mathrm{L}$ & $51.6 \pm 2.3$ & $77.9 \pm 2.7$ & $65.6 \pm 3.1$ & $96.9 \pm 2.8$ & $78.3 \pm 2.2$ & $79.5 \pm 4.4$ & $68.4 \pm 3.0$ \\
\hline $40 \mathrm{mg} / \mathrm{L}$ & $81.5 \pm 5.7$ & $92.3 \pm 4.3$ & $81.5 \pm 3.6$ & $94.4 \pm 2.2$ & $92.9 \pm 1.9$ & $90.4 \pm 4.1$ & $82.3 \pm 4.1$ \\
\hline $60 \mathrm{mg} / \mathrm{L}$ & $88.3 \pm 4.1$ & $92.8 \pm 3.5$ & $83.6 \pm 4.5$ & $97.0 \pm 1.7$ & $95.8 \pm 2.8$ & $92.6 \pm 4.0$ & $83.7 \pm 2.3$ \\
\hline
\end{tabular}

Table 3 shows the removal efficiency and flocculation activity at the end of the experiment. Compared with the control, the treatments with higher initial microalgae concentration had greater removal efficiencies and flocculation activities (Figure 3), showing a relationship between flocculation activity and removal efficiency. Previous studies have reported that the green algae $C$. vulgaris and S. obliquus could be used to remove $\mathrm{PO}_{4}^{3-}$ from the difference of wastewaters $[15,34,35,37]$. Other studies suggested that the immobilized or flocculated form of microalgae is more effective than free form for nutrient removal in wastewater treatment $[13,15,35,38]$. Our results are consistent with Nguyen et al. [13] that bioflocculation formation of microalgae enhanced nutrient removal from wastewater effluent. Naturally, phosphate seems to be depleted from the medium through different mechanisms including adsorption onto the cells surface, assimilation by the algae biomass or chemical precipitation [17, 34]. Previous studies have demonstrated that assimilation into biomass and adsorption were the main biotic processes of elimination of phosphorus in microalgae $[17,34]$.

3.5. Removal of $\mathrm{BOD}_{5}$ and $\mathrm{COD}$. The COD removal efficiencies varied a little among different initial microalgae concentrations (Figure 2(e)). While removal rates of only
$73.5 \%, 78.4 \%$ and $79.5 \%$ were achieved for $10 \mathrm{mg} / \mathrm{L}, 20 \mathrm{mg} / \mathrm{L}$ and $30 \mathrm{mg} / \mathrm{L}$ of microalgae concentration, respectively, removal rates for $40 \mathrm{mg} / \mathrm{L}$ and $60 \mathrm{mg} / \mathrm{L}$ are up to $90.4 \%$ and $92.6 \%$, respectively (Table 3 ). The concentration of COD decreased gradually during the experiment course. The removal rates of $\mathrm{BOD}_{5}$ were almost the same trend with $\mathrm{COD}$ removal pattern and showed Figure 2(f). Higher removal rates were also found in the treatments with higher initial microalgae concentrations. There is a relationship between flocculation activity in the treatments with the removal efficiencies of $\mathrm{COD}$ and $\mathrm{BOD}_{5}$. Higher flocculation activity resulted in higher removal rates in all treatments. Nguyen et al. [38] investigated the ability to removal of COD and $\mathrm{BOD}_{5}$ in seafood wastewater; results indicated that the removal rates of $\mathrm{COD}$ and $\mathrm{BOD}_{5}$ were $88 \%$ and $81 \%$, respectively, under sunlight mode and $81 \%$ and $74 \%$ under fluorescent illumination, respectively, as clear formation of flocculation was observed. Previous studies reported that the presence of microalgae in the cultivation medium had increased the consumption of organic as well as inorganic matters [11, 38, 39]. Besides, Wang et al. [28] reported that two different metabolic pathways, i.e., heterotrophic and autotrophic growth of algae under different culture conditions. Green algae can perform heterotrophic growth besides the common autotrophic one of using $\mathrm{CO}_{2}$ as the sole carbon source [40]. The organic substances may play as an 


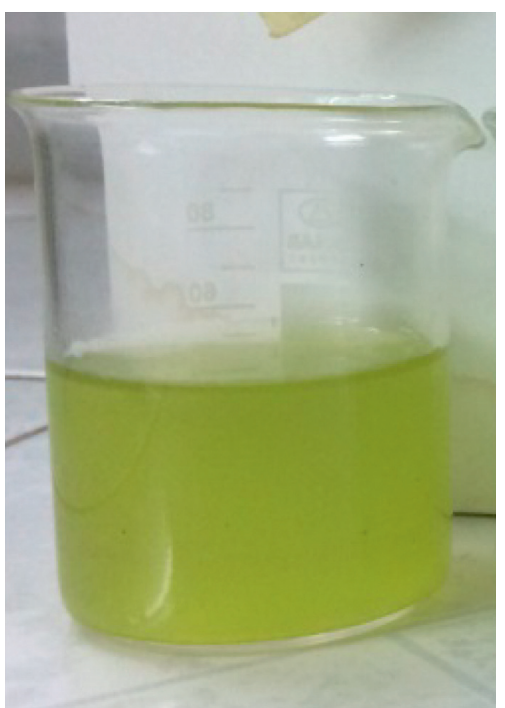

(a)

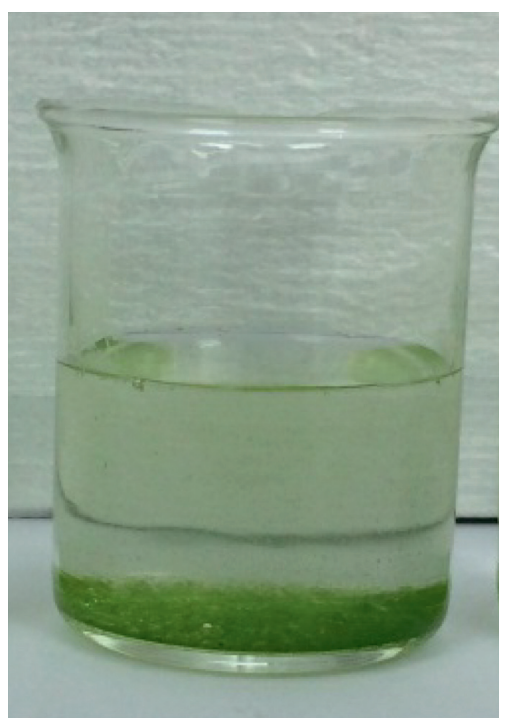

(d)

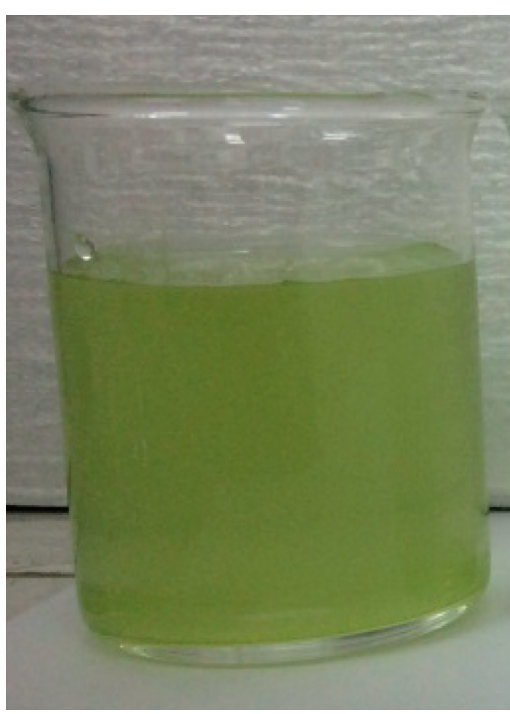

(b)

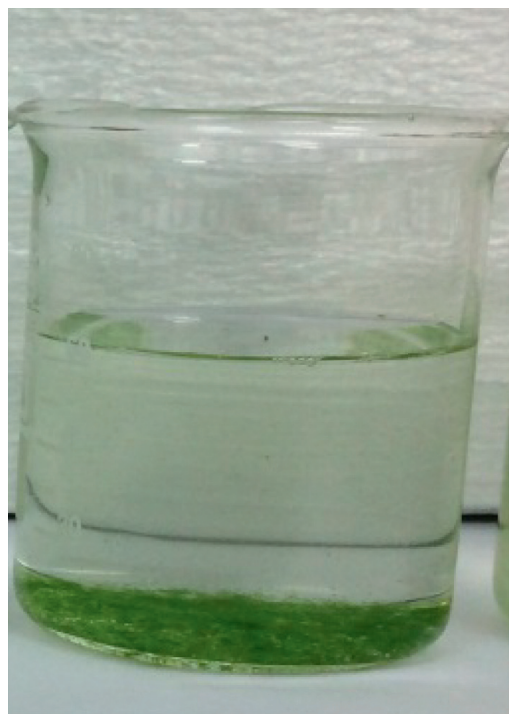

(e)

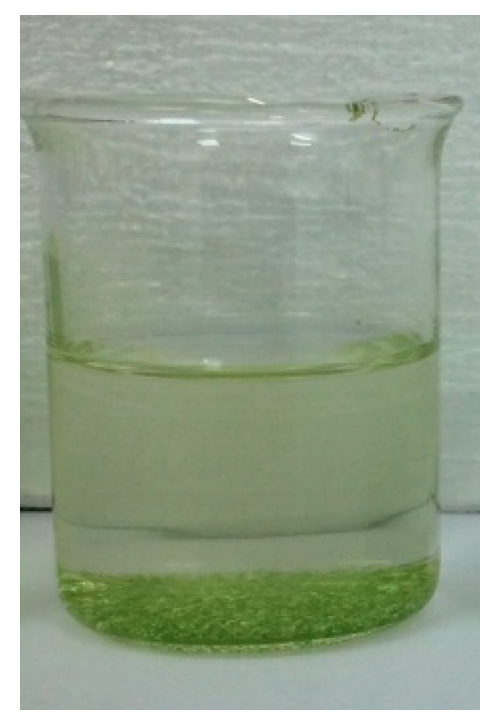

(c)

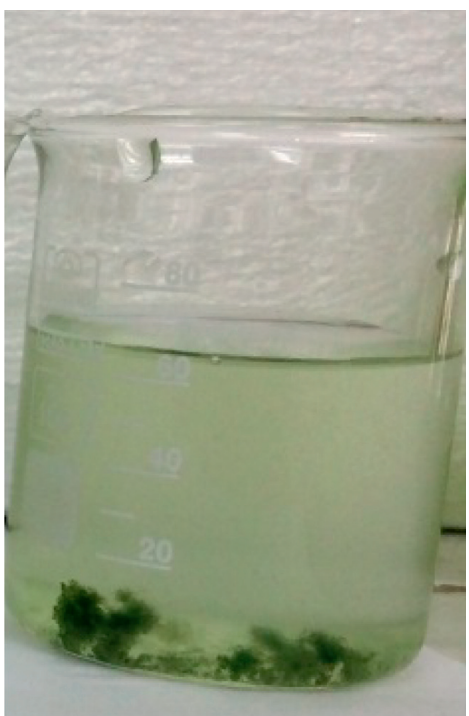

(f)

Figure 3: Flocculation activities in the control (a) and treatment with different concentrations of microalgae: $10 \mathrm{mg} / \mathrm{L}$ (b), $20 \mathrm{mg} / \mathrm{L}$ (c), $30 \mathrm{mg} / \mathrm{L}(\mathrm{d}), 40 \mathrm{mg} / \mathrm{L} \mathrm{(e)}$, and $60 \mathrm{mg} / \mathrm{L}$ (f).

essential organic nutrient for microalgae growth or act as an accessory growth factor. In green algae Chlorella, heterotrophic growth may occur in a much faster way by directly incorporating organic substrate in the oxidative assimilation process for storage material production [28], which is the reason why $\mathrm{COD}$ and $\mathrm{BOD}_{5}$ concentration decreased after algal cultivation. Our results were also in line with the observations of Shen et al. [35] that green microalgae were able to utilize organic carbon for their metabolisms and assimilate organic compounds as a carbon source [41]. These results suggested that the wastewater could be used to provide sufficient nourishment to the algal cell for the metabolism process [42].

The microalgal-bacteria or fungi flocculation and its application in wastewater treatment have been investigated $[13-15,19,20,38]$, but little information is known about the autoflocculation of green algae in wastewater treatment. In this study, AFL occurred when the growth of the microalgae in the fertilizer plant wastewater. The flocculation was exceptionally high in the treatment with 40 and $60 \mathrm{mg} / \mathrm{L}$ of microalgae biomass. Nguyen et al. [38] observed that the AFL occurs when introducing the microgreen algae $C$. vulgaris in seafood wastewater after 8 days. AFL indicates the cell aggregation and adhesion of cells to each other in liquid culture. AFL can occur naturally in certain microalgae to response to some environmental stress such as changes in nutrients, $\mathrm{pH}$, dissolved oxygen (DO), and amount of calcium and magnesium ions in the culture mediums [14]. It is reported that AFL was associated with increased $\mathrm{pH}$ due to the depletion of $\mathrm{CO}_{2}$ concentration due to photosynthesis compared with precipitation of phosphate, magnesium, calcium, and carbonate salts with algal cells [13, 33]. 
In these treatments, the removal rates of nutrients, as well as $\mathrm{COD}$ and $\mathrm{BOD}_{5}$, were relatively higher than other treatments, indicating that the AFL enhances the removal efficiencies. At the end of treatment, the two treatments with the most senior flocculation activities produced the most top elimination of nutrients, as well as $\mathrm{COD}$ and $\mathrm{BOD}_{5}$. Similarly, higher removal percentages of nitrate, phosphates, and COD were reported to associate with bioflocculation process of microalgae $[13,18,19,38]$. In general, algal cell density in flocculation forms is always higher than free forms [20,21]. The high removal efficiency in wastewater treatment with AFL could be attributed to the availability of sufficient oxygen for further mineralization of organic carbon and nutrients because of the high concentration of microalga cells in flocculation formation. In addition, the growth and nutrient removal efficiency may depend on different mixed wavelength ratios. Zhao et al. [9] reported that S. obliquus and C. Vulgaris efficiently removed COD and TP from biogas slurry at a red:blue ratio of $5: 5$ but $S$. obliquus exhibited high $\mathrm{N}$ removal efficiency at a red: blue ratio of 7 : 3. Our results agree with reports by Tang et al. [17] who reported more nutrients, as well as $\mathrm{COD}$ and $\mathrm{BOD}_{5}$ were removed in the treatments with the occurrence of flocculation of $C$. vulgaris compared with the treatment with only free cell form, indicating the enhancement of flocculation in pollutant removal. These results are also in accordance with the study conducted by Nguyen et al. [13] who reported that TSS removal efficiencies of treatment with no flocculation occurrence $(20.6 \pm 10.5 \%)$ were obviously lower than those with the clear formation of flocculation (90.0-95.0\%).

\section{Conclusion}

The present results demonstrated the use of wastewater from a fertilizer plant in the cultivation and harvesting of Scenedesmus sp. Our results indicated that wastewater from fertilizer plants could be used as a cost-effective growth medium for algal biomass. The nutrient removal efficiency by Scenedesmus sp. isolated from the wastewater evidenced that microalgae are potential in removing nitrogen and phosphorous as well as $\mathrm{COD}$ and $\mathrm{BOD}_{5}$ from a highly concentrated nutrient-rich such as fertilizer plant wastewater. The present study highlights the autoflocculation of microalgae could be used as a more practical alternative eco-friendly approach for wastewater treatment using microalgae to eliminate eutrophication.

\section{Data Availability}

The data used to support the findings of this study are included in the article.

\section{Conflicts of Interest}

The authors declare that there are no conflicts of interest regarding the publication of this paper.

\section{Acknowledgments}

This study was funded by the Vietnam Academy of Science and Technology under grant number KHCBSS.02/19-21.

\section{References}

[1] H.-P. Qin, Q. Su, S.-T. Khu, and N. Tang, "Water quality changes during rapid urbanization in the Shenzhen river catchment: an integrated view of socio-economic and infrastructure development," Sustainability, vol. 6, no. 10, pp. 7433-7451, 2014.

[2] A. L. Gonçalves, J. C. M. Pires, and M. Simões, "A review on the use of microalgal consortia for wastewater treatment," Algal Research, vol. 24, pp. 403-415, 2017.

[3] P. M. Glibert, "Eutrophication, harmful algae and biodiversity-challenging paradigms in a world of complex nutrient changes," Marine Pollution Bulletin, vol. 124, no. 2, pp. 591-606, 2017.

[4] J. M. O’Neil, T. W. Davis, M. A. Burford, and C. J. Gobler, "The rise of harmful cyanobacteria blooms: the potential roles of eutrophication and climate change," Harmful Algae, vol. 14, pp. 313-334, 2012.

[5] J. Heisler, P. M. Glibert, J. M. Burkholder et al., "Eutrophication and harmful algal blooms: a scientific consensus," Harmful Algae, vol. 8, no. 1, pp. 3-13, 2008.

[6] T.-L. Pham and M. Utsumi, "An overview of the accumulation of microcystins in aquatic ecosystems," Journal of Environmental Management, vol. 213, pp. 520-529, 2018.

[7] W. M. Lewis, W. A. Wurtsbaugh, and H. W. Paerl, "Rationale for control of anthropogenic nitrogen and phosphorus to reduce eutrophication of inland waters," Environmental Science \& Technology, vol. 45, no. 24, pp. 10300-10305, 2011.

[8] N. C. Boelee, H. Temmink, M. Janssen, C. J. N. Buisman, and R. H. Wijffels, "Nitrogen and phosphorus removal from municipal wastewater effluent using microalgal biofilms," Water Research, vol. 45, no. 18, pp. 5925-5933, 2011.

[9] Y. Zhao, S. Sun, C. Hu, H. Zhang, J. Xu, and L. Ping, "Performance of three microalgal strains in biogas slurry purification and biogas upgrade in response to various mixed lightemitting diode light wavelengths," Bioresource Technology, vol. 187, pp. 338-345, 2015.

[10] L. E. González, R. O. Cañizares, and S. Baena, "Efficiency of ammonia and phosphorus removal from a colombian agroindustrial wastewater by the microalgae Chlorella vulgaris and Scenedesmus dimorphus," Bioresource Technology, vol. 60, no. 3, pp. 259-262, 1997.

[11] Y. Li, Y.-F. Chen, P. Chen et al., "Characterization of a microalga Chlorella sp. well adapted to highly concentrated municipal wastewater for nutrient removal and biodiesel production," Bioresource Technology, vol. 102, no. 8, pp. 5138-5144, 2011.

[12] S.-Y. Chiu, C.-Y. Kao, T.-Y. Chen, Y.-B. Chang, C.-M. Kuo, and C.-S. Lin, "Cultivation of microalgal Chlorella for biomass and lipid production using wastewater as nutrient resource," Bioresource Technology, vol. 184, pp. 179-189, 2015.

[13] T. D. P. Nguyen, T. V. A. Le, P. L. Show et al., "Bioflocculation formation of microalgae-bacteria in enhancing microalgae harvesting and nutrient removal from wastewater effluent," Bioresource Technology, vol. 272, pp. 34-39, 2019.

[14] S. B. Ummalyma, E. Gnansounou, R. K. Sukumaran, R. Sindhu, A. Pandey, and D. Sahoo, "Bioflocculation: an alternative strategy for harvesting of microalgae-an overview,” Bioresource Technology, vol. 242, pp. 227-235, 2017.

[15] Y. Zhao, G. Guo, S. Sun, C. Hu, and J. Liu, "Co-pelletization of microalgae and fungi for efficient nutrient purification and biogas upgrading," Bioresource Technology, vol. 289, Article ID 121656, 2019. 
[16] C. Alcántara, J. M. Domínguez, D. García et al., "Evaluation of wastewater treatment in a novel anoxic-aerobic algal-bacterial photobioreactor with biomass recycling through carbon and nitrogen mass balances," Bioresource Technology, vol. 191, pp. 173-186, 2015.

[17] C.-C. Tang, Y. Tian, H. Liang et al., "Enhanced nitrogen and phosphorus removal from domestic wastewater via algaeassisted sequencing batch biofilm reactor," Bioresource Technology, vol. 250, pp. 185-190, 2018.

[18] J. A. Gerde, L. Yao, J. Lio, Z. Wen, and T. Wang, "Microalgae flocculation: impact of flocculant type, algae species and cell concentration," Algal Research, vol. 3, pp. 30-35, 2014.

[19] M. Shahadat, T. T. Teng, M. Rafatullah, Z. A. Shaikh, T. R. Sreekrishnan, and S. Wazed Ali, "Bacterial bioflocculants: a review of recent advances and perspectives," Chemical Engineering Journal, vol. 328, pp. 1139-1152, 2017.

[20] M. Agunbiade, C. Pohl, and O. Ashafa, "Bioflocculant production from Streptomyces platensis and its potential for river and waste water treatment," Brazilian Journal of Microbiology, vol. 49, no. 4, pp. 731-741, 2018.

[21] D. Vandamme, I. Foubert, and K. Muylaert, "Flocculation as a low-cost method for harvesting microalgae for bulk biomass production," Trends in Biotechnology, vol. 31, no. 4, pp. 233-239, 2013.

[22] V. M. Bhandari, L. G. Sorokhaibam, and V. V. Ranade, "Industrial wastewater treatment for fertilizer industry-a case study," Desalination and Water Treatment, vol. 57, no. 57, pp. 27934-27944, 2016.

[23] S. S. Kilham, D. A. Kreeger, S. G. Lynn, C. E. Goulden, and L. Herrera, "COMBO: a defined freshwater culture medium for algae and zooplankton," Hydrobiologia, vol. 377, no. 1/3, pp. 147-159, 1998.

[24] R. J. Ritchie, "Consistent sets of spectrophotometric chlorophyll equations for acetone, methanol and ethanol solvents," Photosynthesis Research, vol. 89, no. 1, pp. 27-41, 2006.

[25] L. S. Clesceri, A. E. Greenberg, A. D. Eaton et al., Standard Methods for the Examination of Water and Wastewater, American Public Health Association, Washington, DC, USA, 2012.

[26] O. Perez-Garcia, F. M. E. Escalante, L. E. de-Bashan, and Y. Bashan, "Heterotrophic cultures of microalgae: metabolism and potential products," Water Research, vol. 45, no. 1, pp. 11-36, 2011.

[27] C. S. Reynolds, The Ecology of Freshwater Phytoplankton, Cambridge University Press, Cambridge, UK.

[28] L. Wang, M. Min, Y. Li et al., "Cultivation of green algae Chlorella sp. in different wastewaters from municipal wastewater treatment plant," Applied Biochemistry and Biotechnology, vol. 162, no. 4, pp. 1174-1186, 2010.

[29] R. Muñoz and B. Guieysse, "Algal-bacterial processes for the treatment of hazardous contaminants: a review," Water Research, vol. 40, no. 15, pp. 2799-2815, 2006.

[30] E. M. Grima, E. H. Belarbi, F. G. Acién Fernández, A. Robles Medina, and Y. Chisti, "Recovery of microalgal biomass and metabolites: process options and economics," Biotechnology Advances, vol. 20, no. 7-8, pp. 491-515, 2003.

[31] S.-L. Guo, X.-Q. Zhao, C. Wan et al., "Characterization of flocculating agent from the self-flocculating microalga Scenedesmus obliquus AS-6-1 for efficient biomass harvest," Bioresource Technology, vol. 145, pp. 285-289, 2013.

[32] C. Wan, M. A. Alam, X.-Q. Zhao et al., "Current progress and future prospect of microalgal biomass harvest using various flocculation technologies," Bioresource Technology, vol. 184, pp. 251-257, 2015.
[33] A. Sukenik and G. Shelef, "Algal autoflocculation-verification and proposed mechanism," Biotechnology and Bioengineering, vol. 26, no. 2, pp. 142-147, 1984.

[34] L. Delgadillo-Mirquez, F. Lopes, B. Taidi, and D. Pareau, "Nitrogen and phosphate removal from wastewater with a mixed microalgae and bacteria culture," Biotechnology Reports, vol. 11, pp. 18-26, 2016.

[35] Y. Shen, J. Gao, and L. Li, "Municipal wastewater treatment via co-immobilized microalgal-bacterial symbiosis: microorganism growth and nutrients removal," Bioresource Technology, vol. 243, pp. 905-913, 2017.

[36] Q. Dortch, "The interaction between ammonium and nitrate uptake in phytoplankton," Marine Ecology Progress Series, vol. 61, pp. 183-201, 1990.

[37] A. Ruiz-Marin, L. G. Mendoza-Espinosa, and T. Stephenson, "Growth and nutrient removal in free and immobilized green algae in batch and semi-continuous cultures treating real wastewater," Bioresource Technology, vol. 101, no. 1, pp. 58-64, 2010.

[38] T. D. P. Nguyen, T. N. T. Tran, T. V. A. Le, T. X. Nguyen Phan, P.-L. Show, and S. R. Chia, "Auto-flocculation through cultivation of Chlorella vulgaris in seafood wastewater discharge: influence of culture conditions on microalgae growth and nutrient removal," Journal of Bioscience and Bioengineering, vol. 127, no. 4, pp. 492-498, 2019.

[39] I. Woertz, A. Feffer, T. Lundquist, and Y. Nelson, "Algae grown on dairy and municipal wastewater for simultaneous nutrient removal and lipid production for biofuel feedstock," Journal of Environmental Engineering, vol. 135, no. 11, pp. 1115-1122, 2009.

[40] E. R. Burrell, E. W. Inniss, and I. C. Mayfield, “Development of an optimal heterotrophic growth medium for Chlorella vulgaris," Applied Microbiology and Biotechnology, vol. 20, no. 4, pp. 281-283, 1984.

[41] G. Mujtaba and K. Lee, "Advanced treatment of wastewater using symbiotic co-culture of microalgae and bacteria," Applied Chemical Engineering, vol. 27, no. 1-9, 2016.

[42] X. Ma, W. Zhou, Z. Fu et al., "Effect of wastewater-borne bacteria on algal growth and nutrients removal in wastewaterbased algae cultivation system," Bioresource Technology, vol. 167, pp. 8-13, 2014. 